\title{
Dynamics of Lymphocyte Subpopulations in Immune Organs of Chickens Infected with Salmonella enteritidis
}

\author{
A. A. ASHEG, M. LEVKUT, V. REVAJOVÁ, Z. ŠEVČíKOVÁ, L. KOLODZIEYSKI, J. PISTL
}

University of Veterinary Medicine, Košice, Slovak Republic

Recieved June 20, 2002

Accepted September 22, 2003

\begin{abstract}
Asheg A. A., M. Levkut, V. Revajová, Z. Ševčíková, L. Kolodzieyski, J. Pist1: Dynamics of Lymphocyte Subpopulations in Immune Organs of Chickens Infected with Salmonella enteritidis. Acta Vet. Brno 2003, 72: 359-364.

To determine the effect of different doses of Salmonella enteritidis on immunocompetent cells, the thymus, bursa of Fabricius, and peripheral blood were examined. One-day-old chickens were orally infected with $2 \times 10^{2} \mathrm{CFU} / \mathrm{ml}$ (low dose) and $2 \times 10^{8} \mathrm{CFU} / \mathrm{ml}$ (high dose) of S. enteritidis PT4. Subsets of $\mathrm{T}$ lymphocytes (CD3, CD4, and CD8), and BU1b cells using an indirect immunofluorescent method and flow cytometry were analysed on days 7, 10, 14, 21, and 27 postinoculation (dpi). The actual number of lymphocytes in the peripheral blood showed a significant increase in the low dose group $(P<0.05)$ on day 21 pi, and in the high dose group on day 27 pi $(P<0.001)$ compared to controls. The increase of CD3+, CD4+, and CD8+ T cells was observed in both infected groups compared to the controls from day 14 pi, significant on day 21 pi $(P<0.05)$ in the high dose group. The subpopulation of CD8+ was higher also on day $27 \mathrm{pi}(P<0.01)$ compared with the values of the control group. The subpopulation of BU1b+ B cells in both infected groups showed higher values, but without significant differences from controls. The thymus T lymphocytes showed a significant decline in CD3+T cells on day $7 \mathrm{pi}$, whereas CD4+ T cells were significantly $(P<0.05)$ increased on day $7 \mathrm{pi}$ in both infected groups. The bursal lymphocytes showed a decrease in BU1b+ B cells in both infected groups compared with the control group, significant in the high dose group on day $21 \mathrm{pi}(P<0.05)$. These results indicate that $S$. enteritidis infection induced the changes in immunocompetent cells, included cellular and humoral immune response. Salmonella infection accelerated the maturation and differentiation of thymus $T$ cells in the first phase of infection, what was secondarily reflected by increased number of studied $\mathrm{T}$ lymphocyte subpopulations in the peripheral blood from day 14 to 27 after infection. Similarly, it appears that the activation of B cells in bursa of Fabricius caused the decrease number of bursal B lymphocytes and increased number of these cells in the peripheral blood from day 14 to 27 pi in both infected groups.
\end{abstract}

Salmonella enteritidis, immune response, flow cytometry, lymphocyte subpopulations, chickens

Salmonella enteritidis (S. enteritidis) has become the most important cause of human food poisoning throughout the world in recent years. Current research has attempted to identify the defence mechanism of chickens against S. enteritidis (Arnold and Holt 1995). Salmonella invades the intestinal epithelium and stimulates mucosal immunity. In chickens the cell-mediated immune response has been shown to play an important role in host protection against many intracellular pathogens (Schat 1994; Kaufmann 1995; Lillehoj and Trout 1996). Sasai et al. (1997) reported that S. enteritidis infection induces changes in the lymphocyte subpopulations in the spleen and thymus that reflect the dynamics of the host's protective immune response. Although some aspects of cellular immune responses to $S$. enteritidis have been examined in chickens, the exact protective immune mechanism remains to be determined.

In the present study, the percentage of CD3, CD4, CD8 T cells, and BU1b B cells in the thymus, bursa of Fabricius and peripheral blood of one-day-old chickens orally infected with S. enteritidis were investigated.

Address for correspondence:

MVDr. V. Revajová, $\mathrm{PhD}$.

Dept. of Pathological Anatomy

Komenského 73,041 81 Košice, Slovakia
Phone: +42155633819

Fax: + 421556338191

http://www.vfu.cz/acta-vet/actavet.htm 


\section{Materials and Methods}

Chickens

A total of ninety, one-day-old White Plymouth Rock chickens were randomly divided into three groups, containing 30 birds each. The birds were kept in isolation in floor pens of $1 \mathrm{~m}^{2}$ per group on wood shavings that were not changed during the experiment. The pen was lit continuously. The temperature was maintained at that required for the age of the birds $\left(32{ }^{\circ} \mathrm{C}\right.$ at first week and was reduced weekly by about $\left.2{ }^{\circ} \mathrm{C}\right)$. Water and feed were available ad libitum.

Reagents

Mouse monoclonal antibodies (Mab) against chicken CD3, CD4, CD8 T lymphocytes (Scandic, Czech Republic), and BU1b (Southern Biotechnology Associates, Inc., Birmingham, USA) expressed on B cells at a dilution of 1:25 were used for flow cytometry.

Salmonella

Experimental infection was carried out with $S$. enteritidis PT4. Bacterial culture and doses were previously described (Asheg et al. 2001a).

\section{Experimental design}

Chickens in the first and second groups were orally inoculated with $2 \times 10^{2} \mathrm{CFU} / \mathrm{ml}$ (low dose) and $2 \times 10^{8}$ $\mathrm{CFU} / \mathrm{ml}$ (high dose) of S. enteritidis PT4, respectively. Chickens of the third group were used as control animals and obtained a placebo ( $1 \mathrm{ml}$ PBS per os). Five birds from each group were venipunctured and then killed by cervical dislocation on days 7, 10, 14, 21, and 27 post-inoculation (dpi). The peripheral blood, the thymus, and bursa of Fabricius were used for flow cytometry analysis.

White blood cell count (WBC)

Leukocytes were counted by a routine laboratory method using Fried-Lukáčová solution (475 $\mu 1$ solution plus $25 \mu \mathrm{l}$ blood). Differential cell counts were made on blood smears after Hemacolor (Merck, Germany) staining by counting 100 cells per slide.

Flow cytometry in the peripheral blood and organs

The thymus and bursal lymphocytes were removed by teasing through a $70 \mu \mathrm{m}$ mash screen (Heller and Schat 1987) and then isolated on a density gradient - Telebrix (SEVAC, Prague, Czech Republic). Telebrix was also used for the separation of lymphocytes from the peripheral blood. After separation, the lymphocytes were twice washed with phosphate buffer saline (PBS). Fifty $\mu \mathrm{l}$ of cellular suspension $\left(1 \times 10^{6}\right.$ lymphocytes in PBS) and $50 \mu 1$ of specific MoAb (Tab. 1) were mixed and incubated at $4{ }^{\circ} \mathrm{C}$ for $30 \mathrm{~min}$. After incubation the cells were washed twice in the PBS and pellets were mixed with $25 \mu \mathrm{l}$ of the secondary antibody (FITC-conjugated goat antimouse immunoglobulin; Dakopatts, Germany) in a dilution of 1:50 and incubated in the dark as described above. The cells were washed twice in the PBS and resuspended in $0.5 \mathrm{ml}$ of $1 \%$ paraformaldehyde in PBS.

Samples were analysed by FACScan flow cytometer (Becton Dickinson, Germany). Data on $1 \times 10^{4}$ viable cells were collected using the Cell Quest program (Becton Dickinson, Germany). For the peripheral blood the absolute lymphocyte counts were computed as follows: WBC count $\times \%$ of the relative lymphocytes $\times \%$ lymphocyte subpopulation.

Table 1

Primary monoclonal antibodies used in the experiment

\begin{tabular}{|c|l|c|c|}
\hline Specificity & MoAbs & Isotype & Dilution \\
\hline CD3 & RTMCA1378 & mouse IgG1 & $1: 25$ \\
CD4 & SRTMCA1473 & mouse IgG1 & $1: 25$ \\
CD8 & SRTMCA1377 & mouse IgG1 & $1: 25$ \\
BU1b & $8370-01$ & mouse IgG1 & $1: 25$ \\
\hline
\end{tabular}

Statistical analysis

All data were tested by one-way ANOVA using the Bonferoni test. Differences between the mean values for the groups of chickens were considered significant, when probabilities of less than 0.05 were obtained.

\section{Results}

Thymus

A significant decline in $\mathrm{CD} 3+\mathrm{T}$ cells was determined in both infected groups compared with controls on day $7 \mathrm{pi}(P<0.05)$, whereas CD4+ cells in these groups showed a significant 
increase $(P<0.05)$ on the same day. A significant decrease $(P<0.05)$ was detected in CD8+ cells in the high dose group compared with the control chickens at the end of experiment (day 27 pi). The percentage of BU1b+ showed an increase on day 10 pi in both infected groups, with the highest values in the high dose group on day 14 pi, and in the low dose group on day 21 pi. But the decrease of values in both infected groups was ascertained on day 27 pi compared with the controls (Tab. 2).

Table 2

Relative percentage of subpopulations in thymus in the control and $S$. enteritidis infected group (percentage; mean $\pm \mathrm{SD}$ )

\begin{tabular}{|l|c|c|c|c|c|c|}
\hline \multicolumn{7}{|c|}{ Days after infection } \\
\hline Marker & Groups & 7 & 10 & 14 & 21 & 27 \\
\hline CD3 & control & $77.76 \pm 4.95^{\mathrm{a}}$ & $86.00 \pm 0.00$ & $72.83 \pm 6.81$ & $46.15 \pm 8.49$ & $70.36 \pm 26.99$ \\
& low & $19.06 \pm 12.24^{\mathrm{a}}$ & $58.50 \pm 30.40$ & $70.10 \pm 2.24$ & $69.57 \pm 18.31$ & $46.19 \pm 6.16$ \\
& high & $32.00 \pm 9.01^{\mathrm{a}}$ & $88.19 \pm 3.10$ & $39.16 \pm 15.78$ & $41.33 \pm 18.67$ & $42.51 \pm 0.35$ \\
\cline { 2 - 7 } CD4 & control & $59.30 \pm 1.75^{\mathrm{a}}$ & $63.18 \pm 7.06$ & $64.71 \pm 8.94$ & $54.52 \pm 10.78$ & $60.45 \pm 1.12$ \\
& low & $82.48 \pm 3.25^{\mathrm{a}}$ & $63.40 \pm 0.66$ & $62.18 \pm 4.91$ & $67.02 \pm 9.45$ & $59.59 \pm 2.69$ \\
& high & $75.18 \pm 7.19^{\mathrm{a}}$ & $64.73 \pm 10.36$ & $54.22 \pm 11.05$ & $56.13 \pm 5.69$ & $54.04 \pm 3.18$ \\
\cline { 2 - 7 } CD8 & control & $75.11 \pm 0.77$ & $66.53 \pm 13.28$ & $48.20 \pm 3.34$ & $51.05 \pm 16.55$ & $69.45 \pm 2.61^{\mathrm{a}}$ \\
& low & $70.37 \pm 0.40$ & $78.46 \pm 3.47$ & $38.92 \pm 7.55$ & $40.04 \pm 8.13$ & $71.97 \pm 0.63$ \\
& high & $81.84 \pm 12.03$ & $74.00 \pm 11.31$ & $60.75 \pm 20.11$ & $42.86 \pm 2.81$ & $60.23 \pm 0.16^{\mathrm{a}}$ \\
\cline { 2 - 7 } BU1b & control & $1.10 \pm 0.57$ & $1.84 \pm 0.78$ & $2.80 \pm 1.51$ & $4.72 \pm 2.29$ & $4.94 \pm 2.16$ \\
& low & $0.86 \pm 0.33$ & $2.41 \pm 0.55$ & $2.05 \pm 1.16$ & $7.99 \pm 0.64$ & $3.90 \pm 1.22$ \\
& high & $1.29 \pm 0.92$ & $3.20 \pm 1.27$ & $4.54 \pm 0.26$ & $2.87 \pm 2.26$ & $2.48 \pm 0.26$ \\
\hline
\end{tabular}

a, significant difference of infected groups to control group $(P<0.05)$;

\section{Bursa of Fabricius}

Examination of T cells in bursa showed a non-significant increase in the CD3, CD4 and CD8 positive cells of both infected groups compared with control group on day 27 pi. On the contrary, the decrease of BU1b+ cells of both infected groups was determined from day 10 pi, significant $(P<0.05)$ on day 21 in the high dose group (Tab. 3).

Table 3

Relative percentage of subpopulations in Bursa of Fabricius in control and $S$. enteritidis infected group (percentage; mean $\pm \mathrm{SD}$ )

\begin{tabular}{|l|c|c|c|c|c|c|}
\hline \multicolumn{7}{|c|}{ Days after infection } \\
\hline Marker & Groups & 7 & 10 & 14 & 21 & 27 \\
\hline CD3 & control & $1.53 \pm 0.35$ & $2.73 \pm 0.52$ & $7.94 \pm 1.34^{\mathrm{a}}$ & $6.23 \pm 4.57$ & $1.73 \pm 0.77$ \\
& low & $2.24 \pm 0.62$ & $3.99 \pm 0.52$ & $5.91 \pm 1.53$ & $6.21 \pm 2.59$ & $7.2 \pm 2.83$ \\
& high & $1.37 \pm 1.12$ & $7.34 \pm 3.57$ & $20.24 \pm 4.40^{\mathrm{a}}$ & $6.39 \pm 4.18$ & $17.09 \pm 11.00$ \\
\cline { 2 - 7 } CD4 & control & $2.24 \pm 0.74$ & $2.39 \pm 1.84$ & $4.27 \pm 0.75$ & $3.06 \pm 1.75$ & $1.21 \pm 0.72$ \\
& low & $1.64 \pm 0.33$ & $2.31 \pm 0.74$ & $3.70 \pm 0.19$ & $2.72 \pm 2.02$ & $5.16 \pm 1.19$ \\
& high & $0.92 \pm 0.18$ & $1.52 \pm 0.64$ & $9.40 \pm 4.78$ & $3.92 \pm 2.2$ & $18.46 \pm 13.64$ \\
\cline { 2 - 7 } CD8 & control & $1.64 \pm 1.00$ & $2.05 \pm 1.37$ & $3.93 \pm 0.90$ & $7.84 \pm 2.09$ & $1.23 \pm 0.17$ \\
& low & $1.24 \pm 0.33$ & $2.17 \pm 1.70$ & $4.03 \pm 0.65$ & $5.26 \pm 2.85$ & $4.21 \pm 0.40$ \\
& high & $1.52 \pm 1.07$ & $2.37 \pm 0.08$ & $8.41 \pm 3.07$ & $2.10 \pm 1.00$ & $18.54 \pm 13.12$ \\
\cline { 2 - 7 } BU1b & control & $78.66 \pm 12.29$ & $72.07 \pm 21.97$ & $92.86 \pm 0.31$ & $92.76 \pm 0.16^{\mathrm{a}}$ & $93.50 \pm 7.78$ \\
& low & $90.56 \pm 0.20$ & $64.32 \pm 21.45$ & $82.34 \pm 0.21$ & $69.21 \pm 11.24$ & $67.92 \pm 15.96$ \\
& high & $80.20 \pm 2.19$ & $63.01 \pm 1.25$ & $54.59 \pm 18.19$ & $66.74 \pm 0.01^{\mathrm{a}}$ & $60.76 \pm 22.56$ \\
\hline
\end{tabular}

a, significant difference of infected groups to control group $(P<0.05)$ 


\section{Peripheral blood}

Table 4 summarizes the absolute values of peripheral white blood cells. The total number of leukocytes was non-significantly higher on day 21 pi in infected groups compared with the controls. The actual number of lymphocytes showed a significant increase in the low dose group on day 21 pi $(P<0.05)$, and in the high dose group on day 27 pi $(P<0.01)$ compared with the control. A mild elevation of monocyte numbers was detected in both infected groups on days 14 and 21 pi, whereas the heterophiles had declined in both infected groups on days 21 and $27 \mathrm{pi}$. The actual number of CD3 + T cells had a significant increase in the high dose group on day $21 \mathrm{pi}(P<0.05)$, and no significant elevation was observed in the low dose group (Fig. 1). Also the actual number of CD4+ (Fig. 2), and CD8+ T cells (Fig. 3 ) showed a significant increase in the high dose group compared with the control group on day 21 pi $(P<0.05)$, and day 27 pi $(P<0.01)$. The actual number of BU1b+ B cells had increased values in both the high and low dose groups compared with the control group, but without significance (Fig. 4).

Table 4

Actual numbers of peripheral white blood cells $\left(1 \cdot 10^{9} \cdot 1^{-1} ;\right.$ mean \pm SD)

\begin{tabular}{|l|c|c|c|c|c|c|}
\hline \multicolumn{7}{|c|}{ Days after infection } \\
\hline Marker & Groups & 7 & 10 & 14 & 21 & 27 \\
\hline Leukocytes & control & $5.52 \pm 1.46$ & $9.80 \pm 1.05$ & $6.10 \pm 1.32$ & $12.76 \pm 2.24$ & $13.94 \pm 2.48$ \\
& low & $4.06 \pm 0.46$ & $9.32 \pm 3.69$ & $6.95 \pm 3.8$ & $19.26 \pm 6.52$ & $12.28 \pm 1.22$ \\
& high & $7.60 \pm 4.21$ & $9.74 \pm 1.80$ & $14.22 \pm 7.28$ & $18.24 \pm 5.58$ & $16.10 \pm 2.00$ \\
\cline { 2 - 7 } Lymphocytes & control & $3.99 \pm 0.98$ & $6.33 \pm 0.77$ & $3.87 \pm 0.53$ & $8.06 \pm 0.95^{\mathrm{a}}$ & $8.81 \pm 1.36^{\mathrm{b}}$ \\
& low & $3.45 \pm 0.44$ & $8.19 \pm 3.23$ & $5.57 \pm 2.49$ & $15.86 \pm 4.99^{\mathrm{a}}$ & $9.59 \pm 0.85$ \\
& high & $5.52 \pm 2.70$ & $7.82 \pm 1.15$ & $9.83 \pm 4.80$ & $14.56 \pm 3.72$ & $13.30 \pm 1.44^{\mathrm{b}}$ \\
\cline { 2 - 7 } Heterophils & control & $1.50 \pm 0.62$ & $3.29 \pm 1.22$ & $2.63 \pm 1.28$ & $4.52 \pm 1.41$ & $5.95 \pm 2.80$ \\
& low & $0.55 \pm 0.12$ & $0.97 \pm 0.35$ & $1.18 \pm 1.04$ & $3.13 \pm 1.52$ & $2.34 \pm 0.84$ \\
& high & $1.90 \pm 1.45$ & $1.60 \pm 0.85$ & $3.08 \pm 1.63$ & $3.27 \pm 1.74$ & $2.50 \pm 0.60$ \\
\cline { 2 - 7 } Monocytes & control & $0.05 \pm 0.01$ & $0.23 \pm 0.09$ & $0.14 \pm 0.07$ & $0.18 \pm 0.06$ & $0.30 \pm 0.09$ \\
& low & $0.06 \pm 0.02$ & $0.17 \pm 0.15$ & $0.26 \pm 0.25$ & $0.46 \pm 0.18$ & $0.38 \pm 0.19$ \\
& high & $0.19 \pm 0.11$ & $0.31 \pm 0.08$ & $0.30 \pm 0.18$ & $0.41 \pm 0.18$ & $0.30 \pm 0.08$ \\
\hline
\end{tabular}

a, significant difference of low dose group compared with control group $(P<0.05)$;

$\mathrm{b}$, significant difference of high dose group compared with control group $(P<0.001)$

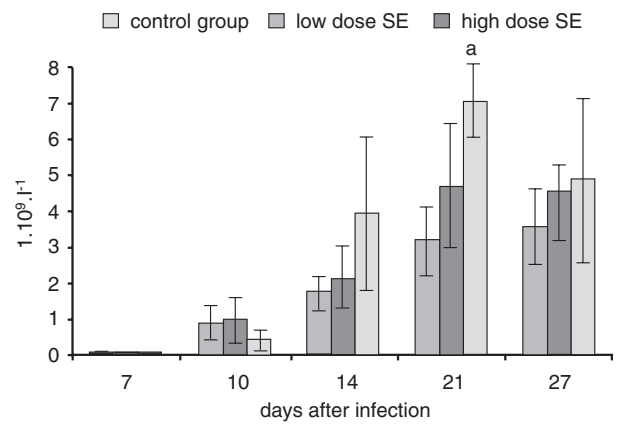

Fig. 1. Actual number of CD3 positive $\mathrm{T}$ cells in the peripheral blood of control and $S$. enteritidis infected group (a, significant difference $P<0.05$ )

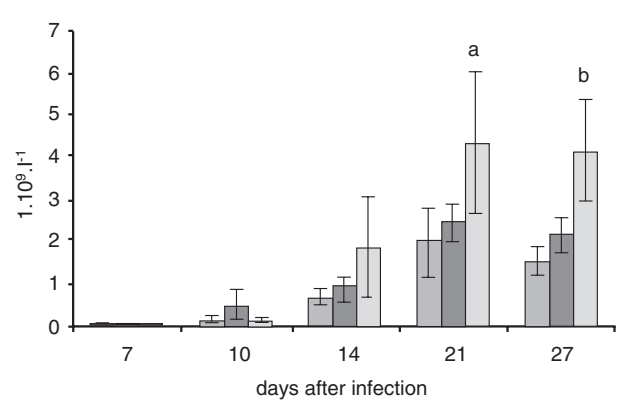

Fig. 2. Actual number of CD4 positive T cells in the peripheral blood (a, significant difference $P<0.05$; b, $P<0.01$ of experimental groups in comparing to the control group). For legend, see Fig. 1. 


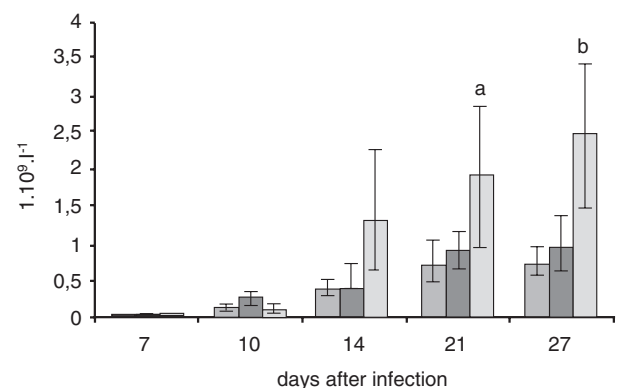

Fig. 3. Actual number of CD8 positive T cells in the peripheral blood of control and $S$. enteritidis infected group (a, significant difference $P<0.05$; b, $P<0.01$ ). For legend, see Fig. 1.

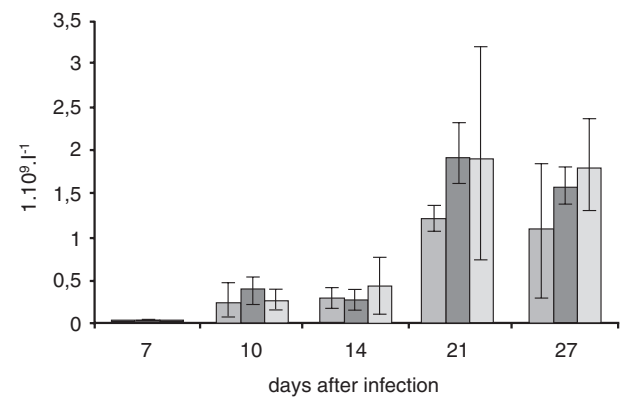

Fig. 4. Actual number of BU1b positive B cells in the peripheral blood of control and $S$. enteritidis infected group. For legend, see Fig. 1.

\section{Discussion}

In our study, the immunocompetent cells in the thymus, Bursa of Fabricius, and peripheral blood after $S$. enteritidis infection of one-day-old chickens, were evaluated. At the first sampling significant changes of CD3+ and CD4+ T cells were found in the thymus. This finding documents the primary role of thymus cells in the protective immune response against $S$. enteritidis infection. Similar results were published by Sa sai et al. (1997) in the study of lymphocyte subpopulations in chickens inoculated with $S$. enteritidis.

In the peripheral blood the immunocompetent cells reflected the $S$. enteritidis infection from day 21 of infection. It is interesting, that the increase in CD4+ T cells in the peripheral blood followed the increase of these cells in the thymus. The increase in CD4+ and CD8+ $\mathrm{T}$ cells in the peripheral blood may indicate higher production of macrophage activating factors such as IFN- $\gamma$ and IL-2, which are crucial for protection against intracellular microbial pathogens (Mosmann and Coffman 1989). Briles et al. (1986) demonstrated that Salmonella-immune T lymphocytes secrete factors that activate macrophages to kill Salmonella typhimurium, and Kauffman (1988) observed that CD8+ T lymphocytes mediate the cytolysis of Salmonella-infected target cells in an IFN-dependent mechanism.

A significant decrease in BU1b+ B cells in the Bursa of Fabricius in the infected group can be connected with these cells moving into peripheral blood. Our results indicate a tendency of BU1b+ B cells to increase in the circulatory blood system. This is in agreement with study of Paramithiotis and Ratcliffe (1993) who found emigrant bursal B-cells primarily in the blood and spleen. As with the results obtained earlier, which supported the assumption of cells moving from the bursa of Fabricius, we found a significant increase in the number of BU1b+ B cells in the caecum and an increase in the percentage of splenic BU1b+ cells in both inoculated groups (Asheg et al. 2001b).

Phagocytic cells such as macrophages and heterophils migrate to the area of inflammation invaded by $S$. enteritidis. In our study there was a tendency in the number of phagocytic cells in the peripheral blood to change.

These results indicate that $S$. enteritidis infection induced the changes in immunocompetent cells included cellular and humoral immune response. Salmonella infection accelerated the maturation and differentiation of thymus $\mathrm{T}$ cells in the first phase of infection, what was secondarily reflected by increased number of studied T lymphocyte subpopulations in the peripheral blood from day 14 to 27 after infection. Similarly, it appears that the activation of B cells in bursa of Fabricius caused the decrease number of bursal $\mathrm{B}$ lymphocytes and increased number of these cells in the peripheral blood from day 14 to 27 pi in both infected groups. 


\section{Infekcia kurčiat Salmonella enteritidis a dynamika subpopulácií lymfocytov v imunitných orgánoch}

Jednodňové kurčatá boli perorálne infikované nízkou $\left(2 \times 10^{2} \mathrm{KTZ} / \mathrm{ml}\right)$ a vysokou $(2 \times$ $10^{8} \mathrm{KTZ} / \mathrm{ml}$ ) infekčnou dávkou $S$. enteritidis PT4. Periférna krv, burza a týmus boli odoberané a vyšetrované za účelom stanovenia účinku rozdielnych dávok na imunokompetentné bunky.

Subpopulácie T lymfocytov (CD3, CD4 a CD8) a BU1b B buniek použitím nepriamej imunoflorescenčnej metódy a prietokovej cytometrie boli analyzované na 7, 10, 14, 21 a 27 deň po infekcii (pi). Absolútny počet lymfocytov v periférnej krvi ukázal signifikantné zvýšenie v skupine s nízkou infekčnou dávkou $(P<0,05)$ na 21 . deň pi, a s vysokou infekčnou dávkou na 27. deň pi. $(P<0,001)$ v porovnaní s kontrolami. Zvýšenie CD3+, CD4+ a CD8+ T buniek bolo pozorované u oboch infikovaných skupín oproti kontrolám od 14. dňa pi, so signifikanciou na 21 . deň $(P<0,05)$ po aplikácií vysokej infekčnej dávky. Subpopulácia CD8+ T buniek bola zvýšená u tejto skupiny tiež na 27. deň pi $(P<0,01)$ oproti kurčatám kontrolnej skupiny. Subpopulácia BU1b+ B buniek u oboch infikovaných skupín preukázala vyššie hodnoty v porovnaní s kontrolnými skupinami, ale bez signifikantných rozdielov. Týmusové T lymfocyty ukázali signifikantný pokles CD3+ T buniek na 7. deň pi, kým CD4+ T bunky boli signifikantne zvýšené na 7. deň pi u oboch infikovaných skupín. Lymfocyty burzy ukázali pokles BU1b+ B buniek oboch infikovaných skupín oproti kontrolám, so signifikantnostou po vysokej infekčnej dávke na 21. deň pi $(P<0,05)$. Salmonelová infekcia urýchlila dozrievanie a diferenciáciu $\mathrm{T}$ buniek $\mathrm{v}$ týmuse $\mathrm{v}$ prvej fáze infekcie, čo sa sekundárne prejavilo zvýšeným počtom jednotlivých subpopulácií T lymfocytov v periférnej krvi od 14. do 27. dňa po infekcii. S tým súvisel aj pokles počtu BU1b lymfocytov v burze Fabricii v uvedených dňoch u infikovaných kurčiat obidvoch skupín.

\section{Acknowledgement}

This study was supported by the Scientific Agency of the Slovak Academy of Sciences VEGA, Grant No. $1 / 8117 / 01$

\section{References}

ARNOLD, JW, HOLT, PS 1995: Response to Salmonella enteritidis infection by the immunocompromised avian host. Poultry Sci 74: 656-665

ASHEG, AA, FEDOROVÁ, V, PISTL, J, LEVKUT, M, REVAJOVÁ, V, KOLODZIEYSKI, L, ŠEVČÍKOVÁ, Z, PILIPâINEC, E 2001a: Effect of low and high doses of Salmonella enteritidis PT4 on experimentally infected chicks. Folia Microbiol 46: 459-462

ASHEG, AA, LEVKUT, M, REVAJOVÁ, V, ŠEVČÍKOVÁ, Z, KOLODZIEYSKI, L, PISTL, J 2001b: T lymphocyte subpopulations and BU1b positive cells in the caecum and spleen of chicks infected with Salmonella enteritidis. Histochem J 33: 469-497

BRILES, DE, BENJAMIN, WJR, POSEY, B, MICHALEK, SM, MCCHEE, JR 1986: Independence of macrophage activation and expression of the alleles of the Ity (immunity to S. typhimurium) locus. Microb Pathogenesis 1: 33-41

HELLER, ED, SCHAT, KA 1987: Enhancement of natural killer cell activity by Marek's disease vaccines. Avian Pathol 16: 51

KAUFFMAN, SH 1988: CD8+ T lymphocytes in intracellular microbial infection. Immunol Today 9: 168-174

KAUFMANN, SH 1995: Immunity to intracellular microbial pathogens. Immunol Today 16: 338-342

LILLEHOJ, HS, TROUT, JM 1996: Avian gut associated lymphoid tissues and intestinal immune response to Eimeria parasites. Clin Microbiol Rev 9: 349-360

MOSMANN, TR, COFFMAN, RL 1989: TH1 and TH2 cells; different patterns of lymphokine secretion lead to different functional properties. Annu Rev Immunol 7: 145-173

PARAMITHIOTIS, E, RATCLIFFE, MJ 1993: Bursa-dependent subpopulations of peripheral B lymphocytes in chicken blood. Eur J Immunol 23: 96-102

SASAI, K, YOSHIMURA, K, LILLEHOJ, HS, WITHANAGE, GSK, FUKATA, T, BABA, E, ARAKAWA, A 1997: Analysis of splenic and thymic lymphocytes subpopulation changes in chickens infected with Salmonella enteritidis. Vet Immunol Immunopathol 59: 355-363

SCHAT, KA 1994: Cell-mediated immune effector function in chickens. Poultry Sci 73: 1077-1081 